This article is licensed under the Creative Commons Attribution-NonCommercial 4.0 International License (CC BY-NC) (http://www.karger.com/Services/OpenAccessLicense). Usage and distribution for commercial purposes requires written permission.

\title{
Splenic Injury Following Endoscopic Retrograde Cholangiopancreatography: A Case Report and Literature Review
}

\author{
Richard Lee ${ }^{a, d} \quad$ Alexander Huelsen ${ }^{a, d} \quad$ Nivene Saad $^{b, d}$ \\ Peter Hodgkinson ${ }^{c} \quad$ Luke F. Hourigan ${ }^{a, d}$ \\ a Department of Gastroenterology and Hepatology, Princess Alexandra Hospital, \\ Woolloongabba, QLD, Australia; ${ }^{b}$ Department of Radiology, Princess Alexandra Hospital, \\ Woolloongabba, QLD, Australia; ${ }^{\mathrm{C}}$ Department of Hepatopancreatobiliary and Transplant \\ Surgery, Princess Alexandra Hospital, Woolloongabba, QLD, Australia; ${ }^{d}$ School of \\ Medicine, University of Queensland, St Lucia, QLD, Australia
}

\section{Keywords}

Endoscopic retrograde cholangiopancreatography $\cdot$ Splenic injury $\cdot$ Haematoma

\begin{abstract}
Splenic injury following endoscopy is a rare but potentially fatal complication. While this has been found to occur more frequently after colonoscopy, splenic injury following endoscopic retrograde cholangiopancreatography (ERCP) remains highly uncommon since its first reported case in 1989. Indeed, there have been only 19 such cases reported in the English, German, and Spanish literature collectively over the past 27 years. We report on a 59-yearold woman who developed a peri-splenic haematoma diagnosed on abdominal computed tomography the day following ERCP and stenting for Mirizzi syndrome. The patient was treated conservatively and made a full recovery. We reviewed all cases of post-ERCP splenic injuries reported to date and discuss the published opinions on the likely mechanism of inju-
\end{abstract}




\section{Case Reports in Gastroenterology}

Case Rep Gastroenterol 2017;11:241-249

(c) 2017 The Author(s). Published by S. Karger AG, Basel www.karger.com/crg

Lee et al.: Splenic Injury Following Endoscopic Retrograde Cholangiopancreatography: A Case Report and Literature Review

ry, predisposing factors, presenting features, investigation, and treatment options. Ultimately, patient outcome relies on clinical suspicion of this rare complication following ERCP.

(C) 2017 The Author(s)

Published by S. Karger AG, Basel

\section{Introduction}

Endoscopic retrograde cholangiopancreatography (ERCP) is a well-established modality in the management of pancreaticobiliary conditions. The procedure carries with it several well-recognised complications, as well as other much less common ones such as splenic injury, which can be associated with significant morbidity or mortality. Since the first reported case of post-ERCP splenic injury in 1989, there have been a total of only 19 cases reported to date in the English, German and Spanish literature [1-19]. Herein, we report on a patient who had a peri-splenic haematoma following ERCP and was successfully managed conservatively. We also review in detail all of the published cases to better understand this rare complication.

\section{Case Report}

A 59-year-old woman presented to the hospital with progressive right upper quadrant abdominal pain for 7 days accompanied by profound jaundice. Prior to this admission, she had presented to another hospital 7 months previously with similar symptoms and was diagnosed with choledocholithiasis. She underwent an ERCP with sphincterotomy and stenting of the common bile duct but did not return for a planned cholecystectomy and removal of stent. Her past medical history included untreated hepatitis $C$ without cirrhosis, intravenous drug use, alcohol abuse and a previous laparotomy for ovarian cystectomy. Her regular medications included methadone $80 \mathrm{mg}$ daily and escitalopram $40 \mathrm{mg}$ daily. At presentation, her blood pressure was $104 / 70 \mathrm{~mm} \mathrm{Hg}$ and all other vital signs were within normal limits.

Physical examination revealed a soft abdomen with tenderness in the right upper quadrant. Her liver function tests were elevated: bilirubin $120 \mu \mathrm{mol} / \mathrm{L}$ (normal, $<20 \mu \mathrm{mol} / \mathrm{L}$ ), alkaline phosphatase 1,490 U/L (normal, 30-110 U/L), gamma-glutamyl transferase 850 $\mathrm{U} / \mathrm{L}$ (normal, <38 U/L), alanine transaminase $196 \mathrm{U} / \mathrm{L}$ (normal, <34 U/L) and aspartate aminotransferase $145 \mathrm{U} / \mathrm{L}$ (normal, $<31 \mathrm{U} / \mathrm{L}$ ). Her coagulation studies were all within normal limits. A liver ultrasound demonstrated cholelithiasis with evidence of intrahepatic and proximal extrahepatic bile duct dilatation. She also underwent liver magnetic resonance imaging with a magnetic resonance cholangiopancreatography, which revealed a large impacted stone in the neck of the gallbladder causing obstruction of the common hepatic duct, just proximal to the previously inserted stent, associated with extensive pre-stenotic, intraand extrahepatic ductal dilatation which was in keeping with Mirizzi syndrome. An ERCP was subsequently performed. The stent was removed with a basket and the common bile duct was cannulated easily through the pre-existing sphincterotomy. The cholangiogram confirmed tight stenosis in the upper third of the main bile duct in keeping with magnetic resonance cholangiopancreatography findings. The stricture was stented with a $10 \mathrm{Fr}$ by 12 


\section{Case Reports in \\ Gastroenterology}

Case Rep Gastroenterol 2017;11:241-249

(c) 2017 The Author(s). Published by S. Karger AG, Basel www.karger.com/crg

Lee et al.: Splenic Injury Following Endoscopic Retrograde Cholangiopancreatography: A Case Report and Literature Review

$\mathrm{cm}$ straight plastic stent. The procedure was technically difficult requiring a sustained long scope position to achieve biliary cannulation and stent placement.

Approximately $4 \mathrm{~h}$ after the procedure, routine nursing observations identified newly developed hypotension with a blood pressure of $83 / 50 \mathrm{~mm} \mathrm{Hg}$ and a heart rate of 70 beats/min. The patient was otherwise asymptomatic, afebrile and did not complain of any abdominal pain. Physical examination did not reveal any abdominal tenderness or signs of peritonitis and there was no evidence of gastrointestinal bleeding or overt dehydration. Following the administration of $500 \mathrm{~mL}$ of intravenous colloid (4\% albumin), her systolic blood pressure stabilised at $103 \mathrm{~mm} \mathrm{Hg}$ which was similar to that on admission. On the next morning, routine blood tests showed a haemoglobin level of $57 \mathrm{~g} / \mathrm{L}$ compared to $91 \mathrm{~g} / \mathrm{L}$ before the procedure (normal, 120-160 g/L). Platelet count and coagulation studies were unchanged and within normal limits. She remained haemodynamically stable and physical examination was again unremarkable, and without evidence of gastrointestinal or any other obvious source of bleeding. Given that the ERCP and stent exchange were uneventful and performed through a pre-existing sphincterotomy, a gastrointestinal bleeding source was felt to be unlikely and an urgent abdominal and pelvic computed tomography (CT) scan was organised. The CT showed a peri-splenic haematoma and moderate volume of hyperdense abdominal free fluid, consistent with a haemoperitoneum (Fig. 1). Considering she was haemodynamically stable, a decision was made for conservative management including a blood transfusion of 3 units of packed cells. In the next $48 \mathrm{~h}$, the patient made an uneventful recovery and was subsequently discharged from hospital with a plan for an eventual elective cholecystectomy. She was followed up as an outpatient 3 weeks later; she was clinically well with normalrange haemoglobin and bilirubin.

\section{Discussion}

Since 1968, when ERCP was first introduced by McCune et al. [20], there has been significant advancement and increased utility of this procedure for diagnostic and now mainly therapeutic purposes in managing pancreaticobiliary conditions. Common complications of this procedure as reported by the American Society for Gastrointestinal Endoscopy (ASGE) in 2012 include pancreatitis (approx. 3.5\%), haemorrhage (especially following sphincterotomy; $1.3 \%)$, cholangitis (1\% or less), cardiopulmonary complications $(1 \%)$, perforation (0.1-0.6\%) and overall mortality (0.33\%) [21]. Splenic-related injuries have always been considered a rare but recognised complication of endoscopy, owing to the close anatomical proximity of the spleen to the stomach and colon. Other reported rare complications of ERCP include liver laceration and disruption of the transverse mesocolon with resultant colonic ischaemia $[1,2]$. Prior to 1975, 2 large case series comprising over 12,000 patients who underwent colonoscopy and endoscopy did not find a single case of splenic injury [3]. As of 2014, Weaver et al. [4] reported that there were over 60 cases of splenic injury following colonoscopy but only 13 reports of a similar injury after ERCP in the literature.

The first case of splenic injury following ERCP was reported by Trondsen et al. [5] in 1989. A female patient admitted with acute gallstone pancreatitis was found to have suffered a complete avulsion of the splenic capsule necessitating splenectomy approximately $15 \mathrm{~h}$ after ERCP. Since then, similar cases have been reported over the following 27 years albeit of 


\section{Case Reports in Gastroenterology}

Case Rep Gastroenterol 2017;11:241-249

(c) 2017 The Author(s). Published by S. Karger AG, Basel www.karger.com/crg

Lee et al.: Splenic Injury Following Endoscopic Retrograde Cholangiopancreatography: A Case Report and Literature Review

differing patient and procedural characteristics. The types of splenic injuries that occur are limited, and the proposed mechanism of injury and predisposing factors have had little differing opinion among the authors, as will be discussed below. At the time of this report, a total of 19 cases of ERCP-related splenic injury were found in the English, German, and Spanish literature (summarised in Table 1). These published cases included 11 female and 8 male patients with a median age of 57 years (range, 33-82 years).

The exact mechanism(s) of injury to the spleen during ERCP remains unresolved; however, excessive scope-related direct, traction or shear forces appear most likely causative. As the side-viewing duodenoscope is usually advanced into a loop (long) position in order to reach the second part of the duodenum, the scope has to be torqued to the right and withdrawn partially (short position) to bring the ampulla into a satisfactory position for cannulation. This manoeuvre causes initial "bowing" of the endoscope within the stomach, likely translating into direct forces towards surrounding organs including the spleen, followed by torsion on the greater curvature of the stomach. Adjacent viscera that are anatomically attached, such as the spleen, could then be injured by traction forces, manifesting in the form of splenic capsular tears or vascular avulsion [6-12]. A sustained long scope position, as in our case, could therefore be associated with prolonged forces.

There are at least 3 predisposing factors that have been postulated to lead to splenic injury during ERCP (Table 2). Decreased movement between the spleen and adjacent structures, excess traction on the gastrosplenic ligament and direct scope-induced trauma have been hypothesised $[3,13]$. Five cases involved patients with either known or newly diagnosed (intraoperative) chronic pancreatitis, and it has been suggested that calcification and fibrosis of the attaching ligaments preclude any compensatory mobility between the surrounding organs $[2-4,15,16]$. Adhesions from prior abdominal surgery, as in our case, were also found to be associated with splenic injuries for the same reason $[2,12,13,17]$. In fact, given the intimate proximity between the spleen and tail of pancreas, acute and post-ERCP pancreatitis is increasingly recognised as a risk factor for splenic parenchymal injuries [22]. Technically difficult cases due to altered anatomy or other patient factors may result in prolonged procedure time and more scope manipulation, thereby increasing the risk of excessive ligamentous tension and injury. Stomach inflation itself, in the opinion of the authors of at least 2 cases, may well render the highest (and shortest) short gastric vessels vulnerable to avulsion injury $[2,14]$. Alternatively, direct splenic trauma by the duodenoscope is a possibility, which often results in injury to the medial or hilar surface of the spleen [14].

It is worth noting that splenic injuries have occurred even in non-technically difficult procedures, as highlighted by Wu and Katon [1] and Chavalitdhamrong et al. [23]. Of the 19 cases of post-ERCP splenic injuries, 10 procedures were performed without difficulty, 7 were difficult, and in 2 it was unreported. In addition, although therapeutic ERCP historically carries a higher morbidity and mortality than diagnostic ERCP [1,21], the difference was not significantly demonstrated in our review. Seven cases only had diagnostic ERCP performed, while 12 also had therapeutic procedures.

Signs and symptoms that should alert a clinician to a possible splenic injury are not specific and overlap considerably with significantly more common complications of ERCP, such as pancreatitis, perforation and post-sphincterotomy bleeding. The typical presentation may include abdominal pain with or without signs of peritonitis (often left upper quadrant and epigastric), hypotension and/or tachycardia [1-19]. Fever was found in only 1 case who 


\section{Case Reports in Gastroenterology}

Case Rep Gastroenterol 2017;11:241-249

DOI: $10.1159 / 00046851$

(C) 2017 The Author(s). Published by S. Karger AG, Base www.karger.com/crg

Lee et al.: Splenic Injury Following Endoscopic Retrograde Cholangiopancreatography: A Case Report and Literature Review

represented 10 days later - in the setting of a previously known splenic haematoma that became secondarily infected from a skin source and turned into an abscess [14]. Haemoglobin was always significantly decreased ( $>20 \mathrm{~g} / \mathrm{L}$ ) compared to pre-procedure levels. It must also be emphasised that there is a considerably variable time interval between developing symptoms and index ERCP. While someone who complains of acute abdominal pain minutes after the procedure would immediately raise suspicion of a related complication, delayed presentations of up to 6 days have been reported and may be overlooked as an unrelated issue.

Although in 5 out of 19 cases, the patient was taken directly to theatre for emergency laparotomy based on strong clinical suspicion alone, an abdominal CT scan is still considered the test of choice to investigate any suspected severe complication [23, 24]. Alternatively, abdominal ultrasound has also been used in 2 cases which revealed findings that supported the indication for surgery $[5,13]$. Common pathologic findings on CT include moderate to large volume of free fluid (haemoperitoneum), subcapsular or peri-splenic haematoma, and splenic laceration. Often the exact diagnosis can only be ascertained intraoperatively, as in cases due to avulsion of blood vessels and splenic capsular tears.

Management of the patient who has likely suffered a post-ERCP splenic injury does not always entail a laparotomy. In this review, all but one patient made a full recovery either following operative or conservative management. One patient died from Pseudomonas pneumonia and ensuing multi-organ failure after splenectomy [2]. Indeed, management should be tailored to the patient's clinical state and with regard to their haemodynamic stability. Trauma guidelines should also be followed as per any blunt splenic trauma, as the management is similar despite differing mechanisms of injury. Early involvement of the surgical team is prudent for any ERCP-related complication, particularly for splenic injury. A surgical approach is usually indicated in patients who experience haemodynamic compromise despite adequate resuscitation, while those who are clinically stable may well be observed and treated conservatively by an experienced clinician. In select cases, a splenorrhaphy rather than a splenectomy may be considered at laparotomy for stable patients with an identifiable splenic injury that is repairable $[3,10]$. More recently, splenic artery embolisation has emerged as a useful adjunct to non-operative management and is increasingly used in trauma settings.

The patient in our case underwent a technically difficult but successful ERCP with stenting for biliary obstruction, and subsequently experienced an episode of hypotension with no abdominal pain and a drop in haemoglobin the next day without any other concerning features. ERCP-related gastrointestinal bleeding appeared unlikely given that biliary cannulation and stenting was performed through a pre-existing sphincterotomy. The CT showed a peri-splenic haematoma with haemoperitoneum, which we suspect was due to splenic capsular injury, likely associated with forces from a sustained long scope position required to successfully perform ERCP and stent placement. She was treated conservatively and made a full recovery.

In conclusion, splenic injury with splenic haematoma or haemorrhage should be recognised as a rare but clinically significant complication of ERCP. Clinical suspicion should be raised if the procedure has been difficult, requiring a sustained long position of the duodenoscope. Symptoms may include initial asymptomatic post-procedural hypotension, left upper quadrant pain, and/or markedly reduced haemoglobin with no haematemesis or me- 
Lee et al.: Splenic Injury Following Endoscopic Retrograde Cholangiopancreatography: A Case Report and Literature Review

laena. There should be a low threshold for considering CT imaging in this clinical scenario. Consideration should also be given for including the rare risk of splenic injury in the consent information for ERCP.

\section{Statement of Ethics}

Consent for publication has been obtained from the patient.

\section{Disclosure Statement}

The authors declare no conflicts of interest.

\section{References}

1 Wu WC, Katon RM: Injury to the liver and spleen after diagnostic ERCP. Gastrointest Endosc 1993;39:824-827.

-2 Kingsley DD, Schermer CR, Jamal MM: Rare complications of endoscopic retrograde cholangiopancreatography: two case reports. JSLS 2001;5:171-173.

-3 Dixon E, Graham JS, Sutherland F, Mitchell PC: Splenic injury following endoscopic retrograde cholangiopancreatography: a case report and review of the literature. JSLS 2004;8:275-277. Weaver JL, Jones W, Miller KR: Life-threatening splenic rupture after endoscopic retrograde cholangiopancreatography. Am Surg 2014;80:E230-E231. Trondsen E, Rosseland AR, Moer A, Solheim K: Rupture of the spleen following endoscopic retrograde pancreatography (ERCP). Case report. Acta Chir Scand 1989;155:75-76.

6 Ong E, Bohmler U, Wurbs D: Splenic injury as a complication of endoscopy: two case reports and a literature review. Endoscopy 1991;23:302-304.

7 Lewis FW, Moloo N, Stiegmann GV, Goff JS: Splenic injury complicating therapeutic upper gastrointestinal endoscopy and ERCP. Gastrointest Endosc 1991;37:632-633. o AY, Washington M, Fischer MG: Splenic trauma following endoscopic retrograde cholangiopancreatography (ERCP). Surg Endosc 1994;8:692-693. Badaoui R, Ouendo M, Delcenserie R, El Kettani C, Radji M, Ossart M: Injury to the liver and spleen after diagnostic ERCP. Can J Anaesth 2002;49:756-757. Zyromski NJ, Camp CM: Splenic injury: a rare complication of endoscopic retrograde cholangiopancreatography. Am Surg 2004;70:737-739.

11 Ahmad S, Bragg D, Zaitoun AM, Lobo DN: A dangerous loop. Clin Case Rep 2016;4:535-536.

-12 Paredes AH, Williams AM, Vertrees AE, Womeldorph C: Splenic laceration following ERCP. Endoscopy 2013;45:E221-E222.

-13 Villalobos-Garita A, Alvarado-Salazar M, Rodriguez-Quesada G, Paez-Saenz R, Avendano-Alvarado, G, Campos-Goussen C, Barahona-Garcia R, Avalos-Giugliarelli A, Gonzalez-Pacheco O: ERCP and splenic injury. Endoscopia 2014;26:23-25.

14 Furman G, Morgenstern L: Splenic injury and abscess complicating endoscopic retrograde cholangiopancreatography. Surg Endosc 1993;7:343-344.

15 Gaffney RR, Jain V, Moyer MT: Splenic injury and ERCP: a possible risk for patients with advanced chronic pancreatitis. Case Rep Gastroenterol 2012;6:162-165.

-16 Cho CL, Yuen KK, Yuen CH, Chong LC, Chu RW: Splenic laceration after endoscopic retrograde cholangiopancreatography. Hong Kong Med J 2008;14:145-147.

17 Grammatopoulos A, Moschou M, Rigopoulou E, Katsoras G: Splenic injury complicating ERCP. Ann Gastroenterol 2014;27:177-178.

18 Deist TJ, Freytag A: Splenic rupture after ERCP. Z Gastroenterol 2003;41:579-582. 


\section{Case Reports in Gastroenterology}

\begin{tabular}{l|l}
\hline Case Rep Gastroenterol 2017;11:241-249 \\
\hline DOI: $10.1159 / 000468515$ & $\begin{array}{l}\text { (c) } 2017 \text { The Author(s). Published by S. Karger AG, Basel } \\
\text { www.karger.com/crg }\end{array}$ \\
\hline
\end{tabular}

Lee et al.: Splenic Injury Following Endoscopic Retrograde Cholangiopancreatography: A Case Report and Literature Review

19 Cortinas Saenz M, Maldonado Hermosos G, Miota de Llama JI, Moreno Planas JM, Mayor Lopez JC: Rupture of the spleen following endoscopic retrograde cholangiopancreatography. Rev Esp Enferm Dig 2010;102:457-458.

20 McCune WS, Shorb PE, Moscovitz H: Endoscopic cannulation of the ampulla of Vater: a preliminary report. Ann Surg 1968;167:752-756.

21 ASGE Standards of Practice Committee, et al: Complications of ERCP. Gastrointest Endosc 2012;75:467473.

22 Patil PV, Khalil A, Thaha MA: Splenic parenchymal complications in pancreatitis. J Pancreas 2011;12:287-291.

23 Chavalitdhamrong D, Donepudi S, Pu L, Draganov PV: Uncommon and rarely reported adverse events of endoscopic retrograde cholangiopancreatography. Digest Endosc 2014;26:15-22.

24 Pannu HK, Fishman EK: Complications of endoscopic retrograde cholangiopancreatography: spectrum of abnormalities demonstrated with CT. Radiographics 2001;21:1441-1453.
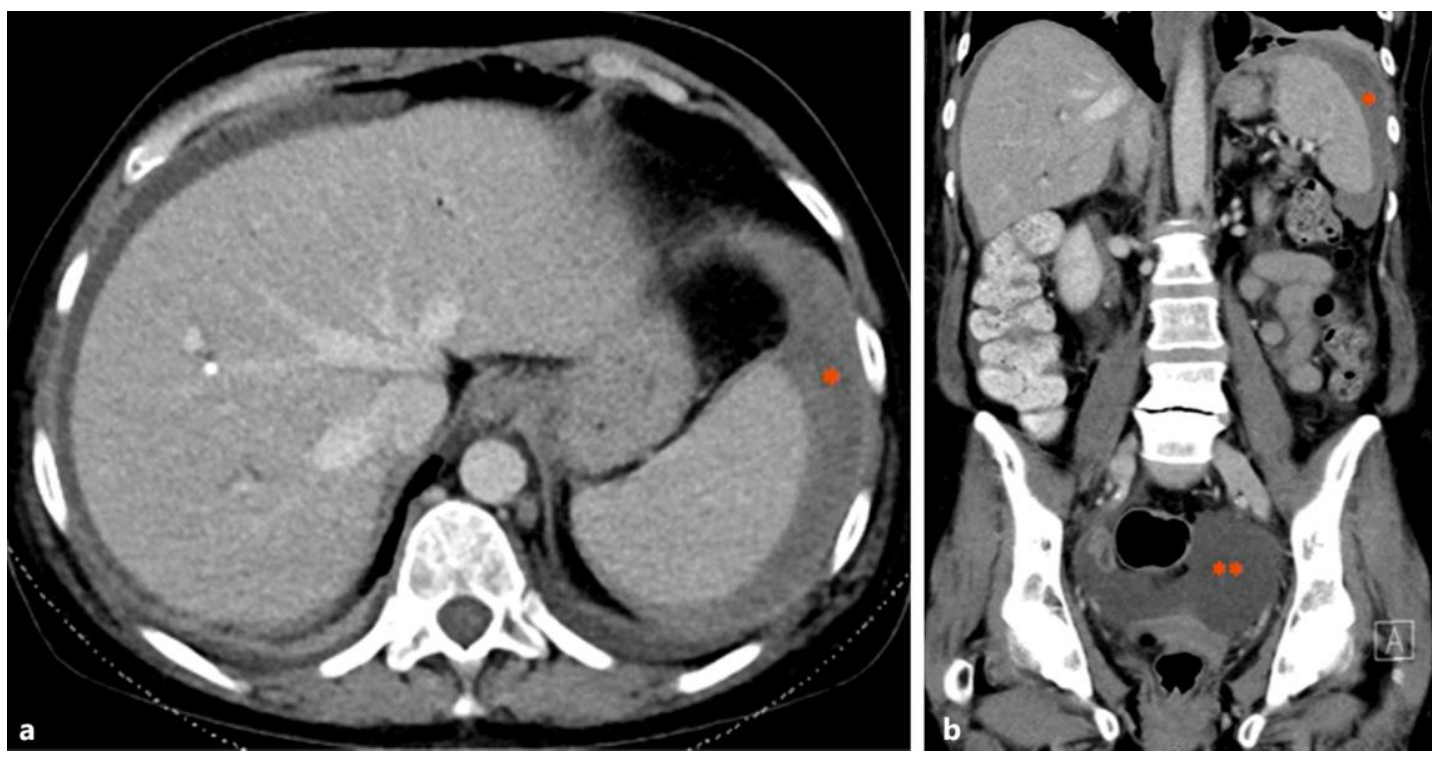

Fig. 1. Axial (a) and coronal (b) CT scans in the portal venous phase showing evidence of peri-splenic haematoma $(*)$ and haemoperitoneum $(* *)$. 


\section{Case Reports in Gastroenterology}

Lee et al.: Splenic Injury Following Endoscopic Retrograde Cholangiopancreatography:

A Case Report and Literature Review

Table 1. Summary of published cases with splenic injuries following ERCP

\begin{tabular}{|c|c|c|c|c|c|c|}
\hline $\begin{array}{l}\text { First } \\
\text { author [Ref.] }\end{array}$ & $\begin{array}{l}\text { Age, years/ } \\
\text { gender }\end{array}$ & Comorbid conditions & Intervention (difficulty) ${ }^{a}$ & $\begin{array}{l}\text { Time to } \\
\text { symptoms }\end{array}$ & $\begin{array}{l}\text { Pathologic } \\
\text { findings }\end{array}$ & Therapy \\
\hline $\mathrm{Wu}[1]$ & $57 / \mathrm{F}$ & Prior abdominal surgery & ERCP (D) & $60 \mathrm{~h}$ & $\begin{array}{l}\text { Splenic capsular } \\
\text { avulsion }\end{array}$ & Splenectomy \\
\hline$\overline{\text { Kingsley [2] }}$ & $54 / \mathrm{F}$ & $\begin{array}{l}\text { Chronic pancreatitis, hepatitis } \\
\text { C, cirrhosis }\end{array}$ & ERCP, stent revision (NA) & $24 \mathrm{~h}$ & Splenic rupture & Splenectomy \\
\hline$\overline{\text { Dixon [3] }}$ & $38 / \mathrm{M}$ & Chronic pancreatitis & ERCP (D) & $\begin{array}{l}\text { Immediately } \\
\text { after ERCP }\end{array}$ & $\begin{array}{l}\text { Splenic capsular } \\
\text { tear }\end{array}$ & Splenectomy \\
\hline Weaver [4] & $66 / \mathrm{M}$ & Chronic pancreatitis & ERCP (NA) & Overnight & $\begin{array}{l}\text { Peri-splenic } \\
\text { haematoma }\end{array}$ & Splenectomy \\
\hline Trondsen [5] & $46 / \mathrm{F}$ & Post-ERCP pancreatitis & ERCP, sphincterotomy (D) & $15 \mathrm{~h}$ & $\begin{array}{l}\text { Decapsulated } \\
\text { spleen }\end{array}$ & Splenectomy \\
\hline Ong [6] & $55 / \mathrm{F}$ & CBD stricture, tumour & ERCP (ND) & $48 \mathrm{~h}$ & Splenic laceration & Splenectomy \\
\hline Lewis [7] & $63 / \mathrm{F}$ & $\begin{array}{l}\text { CBD stricture, pancreatic } \\
\text { head tumour }\end{array}$ & ERCP, stenting, biopsy (D) & $9 \mathrm{~h}$ & $\begin{array}{l}\text { Avulsion of short } \\
\text { gastric vessels }\end{array}$ & Splenectomy \\
\hline Lo [8] & $79 / \mathrm{M}$ & Billroth I anastomosis & ERCP, sphincterotomy (ND) & $48 \mathrm{~h}$ & $\begin{array}{l}\text { Subcapsular } \\
\text { haematoma }\end{array}$ & Conservative \\
\hline Badaoui [9] & $42 / \mathrm{M}$ & Nil & ERCP (ND) & $20 \mathrm{~min}$ & Splenic laceration & Splenectomy \\
\hline Zyromski [10] & $33 / \mathrm{F}$ & Nil & ERCP, sphincterotomy (ND) & $24 \mathrm{~h}$ & $\begin{array}{l}\text { Avulsion of short } \\
\text { gastric vessels }\end{array}$ & Splenectomy \\
\hline$\overline{\text { Ahmad [11] }}$ & $76 / \mathrm{M}$ & Nil & ERCP, sphincterotomy (ND) & $30 \mathrm{~min}$ & $\begin{array}{l}\text { Splenic capsular } \\
\text { tear }\end{array}$ & Splenectomy \\
\hline Paredes [12] & $39 / \mathrm{F}$ & Nil & $\begin{array}{l}\text { ERCP, sphincterotomy, stenting } \\
\text { (ND) }\end{array}$ & $1 \mathrm{~h}$ & Splenic laceration & Splenectomy \\
\hline $\begin{array}{l}\text { Villalobos-Garita } \\
\text { [13] }\end{array}$ & $74 / \mathrm{M}$ & Nil & ERCP, sphincterotomy (ND) & $2 \mathrm{~h}$ & Splenic laceration & Splenectomy \\
\hline Furman [14] & $63 / \mathrm{F}$ & $\begin{array}{l}\text { Prior abdominal surgery, } \\
\text { post-ERCP pancreatitis }\end{array}$ & ERCP, sphincterotomy (ND) & $\begin{array}{l}\text { Not } \\
\text { reported }\end{array}$ & $\begin{array}{l}\text { Subcapsular } \\
\text { haematoma, } \\
\text { splenic abscess }\end{array}$ & $\begin{array}{l}\text { Conservative } \\
\text { (abscess } \\
\text { drained) }\end{array}$ \\
\hline Gaffney [15] & $48 / \mathrm{M}$ & $\begin{array}{l}\text { Chronic pancreatitis, CBD } \\
\text { stricture }\end{array}$ & ERCP, stent exchange (ND) & 6 days & Splenic laceration & Conservative \\
\hline Cho [16] & $63 / \mathrm{F}$ & $\begin{array}{l}\text { Chronic pancreatitis, prior } \\
\text { abdominal surgery }\end{array}$ & ERCP (D) & $18 \mathrm{~h}$ & Splenic laceration & Splenectomy \\
\hline $\begin{array}{l}\text { Grammatopoulos } \\
\text { [17] }\end{array}$ & $64 / \mathrm{M}$ & CBD stricture, tumour & ERCP, stenting (D) & $6 \mathrm{~h}$ & Splenic rupture & Splenectomy \\
\hline Deist [18] & $52 / \mathrm{F}$ & Prior abdominal surgery & ERCP, sphincterotomy (ND) & $8 \mathrm{~h}$ & Splenic rupture & Splenectomy \\
\hline $\begin{array}{l}\text { Cortinas Saenz } \\
\text { [19] }\end{array}$ & $82 / \mathrm{F}$ & Nil relevant & Therapeutic ERCP (D) & $\begin{array}{l}\text { Immediately } \\
\text { after ERCP }\end{array}$ & Splenic rupture & Splenectomy \\
\hline Current case & $59 / \mathrm{F}$ & Prior abdominal surgery & ERCP, stent exchange (D) & $4 \mathrm{~h}$ & $\begin{array}{l}\text { Peri-splenic } \\
\text { haematoma }\end{array}$ & Conservative \\
\hline
\end{tabular}

ERCP, endoscopic retrograde cholangiopancreatography; CBD, common bile duct. a Reported difficulty of procedure: D, difficult; ND, not difficult; NA, not available.

b Time between ERCP and development of symptoms suggestive of splenic injury. c Death from multi-organ system failure. 
\begin{tabular}{l|l}
\hline DOI: $10.1159 / 000468515$ & (C) 2017 The Author(s). Published by S. Karger AG, Basel
\end{tabular} www.karger.com/crg

Lee et al.: Splenic Injury Following Endoscopic Retrograde Cholangiopancreatography: A Case Report and Literature Review

Table 2. Predisposing factors for the development of splenic injuries during ERCP

Decreased movement between spleen and adjacent organs

- Chronic pancreatitis

- Adhesions from prior abdominal surgery

- Smaller abdominal cavities

Excessive traction on attaching ligaments

- Prolonged procedure

- Altered anatomy (e.g., previous gastrectomy)

- Obstructing tumour (e.g., pancreatic head tumour)

- Stomach overinflation

- Large patient body habitus

Direct trauma to spleen by duodenoscope

Liver cirrhosis

Splenomegaly

Post-ERCP pancreatitis

ERCP, endoscopic retrograde cholangiopancreatography. 